$1-1-1988$

\title{
A Lost Episode of "Meeting of the Minds": Posner, Kelman, Holmes, and Pascal
}

Paul J. Heald

University of Georgia School of Law, heald@uga.edu

b

\section{Repository Citation}

Paul J. Heald, A Lost Episode of "Meeting of the Minds": Posner, Kelman, Holmes, and Pascal (1988), Available at: https://digitalcommons.law.uga.edu/fac_artchop/555

This Article is brought to you for free and open access by the Faculty Scholarship at Digital Commons @ University of Georgia School of Law. It has been accepted for inclusion in Scholarly Works by an authorized administrator of Digital Commons @ University of Georgia School of Law. Please share how you have benefited from this access For more information, please contact tstriepe@uga.edu. 


\title{
A LOST EPISODE OF "MEETING OF THE MINDS": POSNER, KELMAN, HOLMES, AND PASCAL'
}

\author{
Paul J. Heald*
}

SET: Four wooden high-backed chairs arranged two to each side of a simple oak desk upon which sits a water canister, ashtray, copies of The Hidden God (by Lucien Goldman, Thody Translation 1964), Economic Analysis of Law (by Richard Posner, 3d. Ed. 1986), The Plague (by Albert Camus), Les Lettres Provinciales (by Blaise Pascal), and several volumes of the Supreme Court Reporter.

SCENE ONE: Mr. Allen enters first, carrying a sheaf of photocopied papers, and sits behind the desk. Next enter Mr. Posner, Mr. Pascal, Mr. Holmes, and Mr. Kelman all carrying similar papers. Holmes and Posner take seats to Allen's right; Kelman and Pascal seat themselves to Allen's left.

MR. ALLEN: Gentlemen, I would like to thank you for coming. I know that Mr. Pascal has had an especially difficult trip. I myself just flew in from the coast, and boy are my arms tired (polite chuckles from Posner and Kelman).

As you know, we are gathered to consider several propositions regarding the common law, although I suspect we may at times expand the scope of our discussion to confront some broader issues of so-called "natural law." I have provided each of you with copies of "The Jurisprudence of Skepticism" by Richard Posner; "The Path of the Law" by Oliver Wendell Holmes; ${ }^{3}$ excerpts from $A$ Guide to Critical Legal Studies by Mark Kelman; ${ }^{4}$ and fragments from Les Pensees of Blaise Pascal. ${ }^{5}$ These texts should have provided some insight into

* Assistant Professor of Law, University of Georgia. A.B. 1980, University of Illinois; A.M. 1982, University of Illinois; J.D. 1988, University of Chicago. I would like to thank Albert Alschuler, Greg Mark, Sean Smith, and Vanessa Sciarra for their encouragement and very helpful comments. I am also grateful for early guidance provided by Michael PalenciaRoth, Robert Nelson, and the Program for Comparative Literature Studies at the University of Illinois. Finally, I would like to thank the Hon. Frank M. Johnson, Jr. for a personal lesson that law can be more than politics.

1. In the 1960's and 70's Steve Allen produced occasional television programs featuring panel discussions as they might have occurred among four historical figures who had lived at different times and who had developed insights into a specific problem. The show was called "Meeting of the Minds." I have borrowed Allen's format in developing this pieceunfortunately his genius is less easy to imitate..

2. 86 MiCH. L. REV. 827 (1988).

3. 10 HARV. L. REV. 457 (1897).

4. M. Kelman, A Guide to Critical Legal Studies (1988).

5. B. PasCal, Pensees (Collier 1960) (Trotter Trans.) The fragments will be cited fol- 
the theories held by your fellow panelists.

To begin, I wonder if each of you could briefly describe your views on the development of the common law?

MR. POSNER: Sure, Steve. Without being too simplistic, I think we can view the common law as primarily a system of rules developed over time by judges to further the end of economic efficiency. I do not mean that each common law judge adopted a global view of classical economics which he applied consciously and rigorously. However, there can be little doubt that, for example, the negligence rules refined in the nineteenth century are demonstrably efficient, consistent, and unexplainable by any purely rights-based theory.

MR. HOLMES: I must agree that common law judges were very much concerned about establishing rules by which men could govern their behavior. These judges were certainly making the law rather than "finding" it. However, I am unwilling to say that the primary force behind their development of the law was economic efficiency. My experience with judges has been that their personal morals, values, prejudices, and social class play too large a role in their decisionmaking to permit the consistent implementation of such a far-reaching substantive principle.

MR. KELMAN: I appreciate both Judge Posner's and Justice Holmes' candor regarding the motivations and decision-making processes of the common law judge. I am gratified to see that formalist babble about judges finding the law of nature is no longer acceptable. However, I violently disagree with the rationalizations of both of my fellow panelists regarding the function (as opposed to the source) of the common law. My examination of the law has found it to be so indeterminate and malleable that it cannot possibly serve the function of providing behavioral guidance. Second, the source of the common law has been so completely dominated by the factors mentioned by Justice Holmes (especially class) that it embodies no neutral values such as "efficiency" (Posner) or "notice of social force" (Holmes). It has merely reflected the needs of a given ruling class for power.

MR. PASCAL: This is all extremely interesting, but . . .

ALLEN: Pardon me for a moment, Blaise?

PASCAL: Certainly.

ALLEN: Given the American legal community's almost total

lowing the numbering system established by Leon Brunschvieg. Hereinafter, citations will be to fragment with an accompanying number. 
ignorance of continental philosophy, I thought I might provide our audience a brief overview of Mr. Pascal's work.

Mr. Pascal is a paradox. And his writings primarily address the question of paradox as they develop one of the first explicitly dialectical approaches to ontology. I fully agree with Lucien Goldmann's view regarding Pascal:

[He is] the first of a long line of thinkers who go beyond-and integrate-both the Christian tradition and the achievements of rationalism and empiricism and create a new moral attitude which is valid today. For me, Pascal is the first modern man. ${ }^{6}$

He emerges as the first "modern man" (and I think Goldmann also had in mind "existential man") by "extending paradox to God himself, and making him both certain and uncertain, present and absent ... and thus opening a new chapter in the history of philosophical thought." 7 Pascal is an anti-rationalist, yet he is as brilliant a mathematician (the arch-rational pursuit) as his acquaintance and contemporary Rene Descartes.

More specifically, Pascal sees man as hopelessly fragmented-his power of reason alone incapable of conferring transcendence. Reason and rationality are signs of man's greatness and the cause of his inevitable failure. Man is at his most God-like when he reasons; for example, science is perhaps man's greatest achievement. Yet reason alone is insufficient to confer transcendence because man is hopelessly broken. Original sin.is manifested in man's inability to rise above himself to establish perfection. God exists, but he is mostly hidden, and in the final analysis man's reason cannot consistently discern justice or truth. Human nature is imperfectable, and reason can accomplish only vague approximations of the God-like.

I thought I'd read you a few quotes from Pascal's collection of thought fragments, Les Pensees, to illustrate not only the substance of his work, but the stylistically fragmented method he used to express himself:

On what shall man found the order of the world which he would govern? Shall it be on the caprice of each individual? What confusion! Shall it be on justice? Man is ignorant of it ... Doubtless there are natural laws; but good reason once corrupted has corrupted all. ${ }^{8}$.

Each thing is partly true and partly false ... This mixture

6. Goldmann, The Hidden God, 171.

7. Goldmann, The Hidden God, 183.

8. Fragment 294, supra note 5. 
dishonors and annihilates it. Nothing is purely true, thus nothing is true, meaning by that pure truth . . . we possess truth and goodness only in part, and mingled with falsehood and evil. ${ }^{9}$

No doubt equality of goods is just; but, being unable to cause might to obey justice, men have made it just to obey might. Unable to strengthen justice, they have justified might, so that the just and the strong should unite, and there should be peace-which is the sovereign good. ${ }^{10}$

HOLMES: Bravo! Well said. I must thank Mr. Allen for providing me with an ally in my struggle to reveal power as the primary legitimating force behind legal rules.

KELMAN: I think you misunderstand our French guest. It seems clear to me that his stance is far closer to mine. He sees no legitimate basis for our laws [quickly flipping through his pages]-If you read further, you will find at fragment 295, "Mine, thine ("This dog is mine', these poor children said, 'this is my place in the sun.'). Here we have the beginning and image of usurpation over all the earth." I think he is merely describing power-not endorsing it.

POSNER: You all forget that $\mathbf{M}$. Pascal and his colleague $\mathbf{M}$. Descartes lay the mathematical foundation for any empirical economic approach to the common law.

PASCAL: If I might say something?

POSNER: Of course.

HOLMES: Please, pardon us. Proceed.

PASCAL: I think all of you, to a certain degree, have a philosophical ally in me, yet I cannot accept any of your conclusions because I completely reject your initial premises. Although none of you bother to consider the question in depth, from what I understand of your works, each of you bases his theories on rather foolish assumptions about the nature of man.

KELMAN: Come now. Surely you don't expect us to become arch-metaphysicians hiding our heads in the bourgeois clouds?

PASCAL: I only expect a justification of your views on the common law.

Judge Posner, for example, clearly assumes that man is a "wealth maximizer." Man is a rational creature seeking to satisfy his tastes and preferences efficiently. I would certainly agree that mankind is a slave to his preferences and tastes-yet I cannot comprehend the as-

9. Fragment 385 , supra note 5 .

10. Fragment 299, supra note 5. 
sertion that he either satisfies them in a rational manner or that the common law facilitated such satisfaction in principle.

POSNER: Please, explain yourself.

PASCAL: First, man is essentially a self-destructive creature. Have you known no alcoholics? Unless you mean to say man has a "taste" for his own misery and self-destruction (which would seem to leave the term "wealth maximization" devoid of any real content), history shows that man seldom gets what he wants or wants what is good for him. If man were truly a wealth maximizer, he should be a happier creature now than he was in my day. I have observed no improvement in man's lot. I once said, "The works of men from century to century end up the same. Both the fruits and malice of the world generally remain the same."11

POSNER: Ahem. That is not to say, however, that the common law did not set the wealth maximization principle in motion.

PASCAL: You are right in seeing that as a separate question. And, in fact, I think your theory fits most of what common law judges did in the tort, contract, and property law contexts. That mankind is not efficient does not mean that man has not strived to create rules which might engender an efficient marketplace. He did not succeed, but $I$ believe you are right in saying he tried in certain areas of the law.

Outside these contexts, however, I think you yourself have provided several disproofs of the efficiency theory.

POSNER: Oh?

PASCAL: For example, selling babies. Although I believe an open market for babies would be wrong, I certainly agree with you that if would be very efficient. Yet, it was, and is, illegal to sell children at common law. Certainly, you agree that in many fields the common law was inefficient?

POSNER: Well, perhaps temporarily, but left alone, I believe those inefficiencies would have been addressed.

PASCAL: But the common law was never left alone, was it? Statutes have always gotten in the way, and that reveals something in itself about man's nature, does it not?

HOLMES: But M. Pascal. What of me? I surely do not fall into the same trap as Judge Posner. I have never posited that any single value has served as the driving force of the common law!

11. Fragment 294, supra note 5. 
PASCAL: No, indeed. In fact, I would go so far as to say that you see no particular "truth" as shaping the common law-unless power is a value in itself. I think that is precisely the weakness of your analysis of the common law. You describe the common law as driven by either consensus (when it responds to society's needs), by the judge himself (acting either arbitrarily or to further a particular interest), or at its worst by formalistic adherence to muddied maxims and unjustified "rules".

Man may be incapable of achieving justice (and I think your critical realism provides us with several hints as to why), but that does not mean that man has not striven for it. Your denial of man's aspiration to the divine, and your refusal to consider that absolute values do exist, has left us with a two-dimensional view of the common law.

KELMAN: I suppose I am in for a similar charge of heresy, $M$. Pascal? I certainly go far beyond Mr. Holmes in de-mystifying the work of the common law judge.

PASCAL: Why? I understand your critique of the common law as somewhat different.

KELMAN: How so?

PASCAL: To me, you see law as being very concerned with values, norms, and justice.

KELMAN: [with a laugh] I do?

PASCAL: You admit that the process of law is concerned with values; you just feel that given the nature of capital, dehumanizing values have been generated and perpetuated by the common law. And as a normative matter, you do believe society should be changed to permit a different vision of "justice" to emerge.

KELMAN: I suppose that's right. As long as my abhorrence of the existing order is recognized. I certainly would not deny that what we call "law" should generate "justice" (keeping in mind that a vastly different conception of justice would be generated after the deconstruction of our current power structures).

PASCAL: Perhaps now would be a good point to begin our discussion of what our conception of "justice" might be.

ALLEN: Pardon me. Although I am interested in exploring the nature of the transcendent values which might underlie the law, you have forgotten to give us your own view of the common law.

PASCAL: Well, I think it is crucial to understand that I believe God exists as do absolute values (which find their source in him).

However, the fact that values exist does not mean-as some nat- 
ural law formalists might have it - that they can be discovered or that they could be implemented if they were discovered. Particular men will never agree: the noble part of man aspires to justice; the creatureliness of man condemns him to eternal gropings at best approximating, but never consistently implementing, justice.

This critical position leads us to a clearer understanding of the common law. The function of the common law, or for that matter any law, is to impose order on values: to create an orderly implementation of values. (Or perhaps as Mr. Kelman's friend Roberto Unger might assert: to create a flexible order which generates values). Either way, a conflict exists. Order, by its nature, is a rational construct. All schemes of order are viewed rationally. Values, by their nature emanating from a hidden God, are not rational. The dynamic of the common law comes from the imposition of rationality (order) on something non-rational (values). This is why the common law is imperfect, and also why it has survived for so long: the conflict within the law mirrors the conflict within human nature itself. The common law's own unsuccessful struggle towards justice mirrors man's own frustrated aspiration. Perhaps no institution better illustrates human nature.

POSNER: Well; I certainly better understand your desire to start from a particular view of human nature.

KELMAN: I simply doubt that M. Pascal's view is the right one.

(Cut to commercial)

SCENE II: The set remains unchanged. Holmes sits riffling through his papers, while Posner and Kelman converse, gesticulating with some animation. Pascal and Allen pour themselves glasses of water.

ALLEN: At this point, I think we must address the issue of natural law. M. Pascal has posited that we cannot understand law without reference to God, albeit a hidden God. I'm interested to hear what we think of Pascal's view and the usefulness of talking about "natural law" in general.

KELMAN: To be honest, I expected nothing less than such nonsensical philosophy from an entrenched member of the seventeenth century French middle class.

ALLEN: Don't you think that's rather unfair? Pascal's contemporaries were completely unlike him. Most of the French middle class were believers in a revealed God or were beginning to accept the 
purely rational views of Descartes; Pascal explicitly rejects both of those positions. What does Pascal have to gain politically by positing a hidden God? By doing so he negates the worldly striving of his bourgeois fellows.

KELMAN: Well, I did not mean to make an ad hominem attack, I merely wanted to point out that claims that "justice" emanates from on high have historically done the majority of the people little good. Such mysticism has only served to permit judges to maintain the economic status quo.

HOLMES: Mr. Kelman certainly has a point about law and politics, but I'm wondering if we could define more precisely the differences between a "revealed" and a "hidden" God, and what we mean when we speak of natural law?

ALLEN: Good question. Mr. Pascal?

PASCAL: Well, a revealed God is the fountainhead of positive law for believers. The law is not left in the dark, so to speak.

POSNER: For example, the law followed by Orthodox Jews or Moslems.

PASCAL: Exactly. And, I think, some of your "fundamentalist" Christians share the same position.

As for natural law in general, my own feeling is that because our God is hidden, we only get glimpses of the truth-a second-hand guess of what is just (somewhat akin to how knowledge is received in Plato's parable of the cave). Natural law exists, but it is beyond our reason.

KELMAN: Well, I give you some points for uniqueness.

ALLEN: Actually, I can think of at least two other theories which might posit unknowable absolute values. First, law might be genetic. It's entirely possible that values and norms are the product of DNA structures modified through evolution. Therefore, our collective gene pool might be advancing certain values without our being capable of divining what they are. This theory is certainly vulnerable to a number of attacks, but it presents a dilemma similar to that posed by M. Pascal.

Second, values might be generated by our unconscious. In The Origin of Consciousness in the Breakdown of the Bi-Cameral Mind, psychology professor Julian Jaynes suggests that as recently as 3000 years ago mankind was not self-conscious. Self-consciousness was a secondary development which left man's original "mind" still opera- 
tive. This other half of ourselves, about which we by definition can know little, may be another apolitical generator of values.

POSNER: I find this speculation extremely interesting. And I think Mr. Allen's examples are right on point-they are certainly as plausible as M. Pascal's theories. But now that we have an idea of what might be the sources of natural law, hasn't it become clear that there is no point in talking about them? At best natural law seems totally deterministic. Genes or Jaynes are the sources of law. Or as a worse alternative, Pascal's God seems so impenetrable as to thwart any advances that different conceptions of law might be able to realize.

Remember, my position is not unprincipled or without norms. Now that we are no longer merely describing the law, I feel free to argue that wealth maximization should be society's most important governing principle. I see no need to feel helpless in the face of infinity, to paraphrase M. Pascal. I am quite willing to adopt a value which I believe will benefit society.

KELMAN: Although I disagree with the particular value Judge Posner would adopt, and I'm not certain exactly which particular values I would establish, I agree with the Judge's position that Pascal's position is paralyzing. I'm not willing to grope for justice; I believe in a deconstruction of current capital systems, and a humane dispute resolution system which would permit the generation of shared community values. That should be our "value."

HOLMES: You speak of the possibility of values coming from man. Even M. Pascal would agree with that. The question is, which values? Without God, how can you be sure your choice is right?

I'm not undergoing a religious conversion here, but my brother Posner and Professor Kelman must recognize that the values they seek to realize are at the whim of political power. They are "true" or "just" only so long as power sustains them. Don't get me wrong. I respect power. Some of my most eloquent opinions were in defense of the power of the majority through a legislature to mold society and change values. As a judge I have been an instrument of political values held by society. You are right in stating that the concept of a hidden God makes value choices agonizing, but given the nature of power, I am not sure why your positions are intrinsically more tenable than Pascal's.

ALLEN: Excuse me, but I might note one personal experience. As we know, Holmes' decisions in the first amendment area seem at 
odds with many of his statements in prior opinions about the need for legislative deference. Although Mr. Brandeis and he talked about the intent of the Framers and developed justifications such as "the marketplace of ideas", I'm not so sure those are the real objections to the suppression of speech. Maybe it simply was unjust to imprison Mr. Abrams for running leaflets off his printing machine. ${ }^{12}$ Maybe, on occasion, extra-rational values may be a basis for decision.

I think I may have perhaps put my finger on the essence of the problem. Don't we all sometimes feel something is right or wrong? I mean even beyond our responses conditioned by our environment? If not, how can we explain Socrates' Apology? Is it really useless to talk about a "higher justice"?

HOLMES: Yes, it is useless. And I think your misreading of my opinions is unfortunately all too common. But, your views do raise an apt question about the nature of justice.

ALLEN: (Ahem) Justice Holmes begins to touch upon our final topic-judicial decisionmaking. Before we begin that, I wonder if $\mathbf{M}$. Pascal could sum up his position on natural law?

PASCAL: I can try. I think that the logical endpoint of my position is perhaps less bizarre than Judge Posner and Professor Kelman seem to think (and maybe not so terribly different from Mr. Allen's little speech). I can make two statements with relative certainty. First, any legal theory based on a rational model of human nature is incomplete. Man is not rational. But neither is man wholly irrational, and so I do not condemn those engaged in the worldly work of shaping the law:

[for] their fault lies not in their quest for tumult, if they did but seek it merely as a diversion to their uses; the evil lies in their seeking it as if the possession of the things which they chase after really were going to make them happy, and this is why they can be accused of vanity. ${ }^{13}$

Therefore, although Judge Posner and Professor Kelman's quest is vain, it is an inevitable part of their nature. A confrontation by them with the hidden God, and a realization of the imperfection of human nature, might not halt their search (nor make it succeed), but rather cause them to proceed less blindly.

Second, although any legal theory based on a rational model of man is incomplete, the attempt to complete the model through the

12. Abrams v. United States, 250 U.S. 616 (1919).

13. Fragment 139 , supra note 5. 
acceptance of man's nature does not yield a utopian vision. The realization of man's nature does not engender the cure-the solution to the paradox of man is Jesus Christ, and his kingdom shall not be found here on Earth.

KELMAN: But then isn't the real end-point withdrawal from society? Goldmann argues fairly strongly that your philosophy denies the world. It would seem you would have little to tell judges who must live in the world and administer the laws of persons!

ALLEN: Goldmann does seem to say that Les Pensees leave little room for participation in society, yet he also points out that $\mathbf{M}$. Pascal's political struggles with the Jesuits on behalf of his fellow Jansenists took place after his so-called "conversion". This may open him to charges of hypocrisy or inconsistency, but we cannot deny his own efforts to change the world.

PASCAL: Mr. Kelman has struck at the heart of the predicament of my existence. I wrote Les Lettres Provinciales in response to what I saw as the laxity of the Jesuits. I supported the Jansenists in their political struggles, while my sister, whose faith I shaped, gave away all her possessions and entered a convent. I, perhaps, should have done the same. This confuses the scholars and myself.

(Allen, eyebrows furrowed, picks the copy of The Plague off of his desk and offers it to Pascal. Holmes lights up a cigarette).

(Cut to commercial)

SCENE III: The set remains unchanged. Pascal is still reading, the others appear relaxed, although not conversing.

ALLEN: We have been engaged in a rather interesting discussion of legal theory. However, I'm sure we all realize that actual cases are decided by judges. In a practical sense, the resolution of discrete disputes is what the law is all about. As a descriptive matter we disagree on exactly how a judge decides a case, but can't we agree that there is a right way to decide a case, and wouldn't it be fruitful to discuss how cases should be decided?

KELMAN: No.

ALLEN: Would you care to elaborate?

KELMAN: You assume a society with judges! The very presumption of adversarial dispute resolution stems from our social conditioning. I strongly suggest that a perfect society (with regrets to $\mathbf{M}$. Pascal) would not have "cases" and "precedents"- but a more humane process. 
ALLEN: So, you refuse to participate?

KELMAN: No. I just wish to make it clear that, as usual, we envision the world we were sold in law school: Any real improvements in judicial decisionmaking will follow changes in political structure.

ALLEN: All right. Objection noted. However, could you tell us, given our current system, how a case should be decided?

KELMAN: Again, you're asking the wrong question. You assume the "case." Your question assumes the rule of law because it assumes the same answer in all similar cases. And, you assume that a method of "legal reasoning" exists which would generate a consistent answer. Hasn't our discussion shown that human law (here I'm sure that M. Pascal at least is with me) is indeterminate and that "legal reasoning" is a fiction?

ALLEN: I'm not so sure we've gone that far, although clearly we have no formalists here.

O.K. How's this? A man commits a crime. He hires an attorney for $\$ 90 /$ hour. The attorney works hard on the case, but the man is convicted. The attorney asks the man for payment. The man refuses to pay and hires a different attorney to prosecute the appeal of his conviction. The first attorney refuses to deliver the man's files and papers to the second attorney until the man pays his bill. Eventually, in order to get his files and papers back, the man signs a promissory note for the amount owed to the first attorney. Upon default of the note, the first attorney then brings suit on the promissory note. The man raises the defense of duress in the signing of the note. Relevant state law holds that: duress is available as a defense; duress must result from a "wrongful" act; a wrongful act could be one that is merely immoral or against public policy; and by statute an attorney has possessory lien on all his client's papers until he is paid. There are no cases in the jurisdiction on point. How should a judge decide the case?

KELMAN: Your hypothetical, despite its complexity, is rather easy to answer. It demonstrates precisely the clash of private property rights and community entitlements that stimulate the most obfuscating legal opinions. First, as a stylistic matter, the judge should explain precisely the reason for his decision. The sort of community values which judges should nurture are not served by formalistic analyses of a particular problem. If the judge feels no pity for dead-beat criminals (he himself wanting people to pay their debts to him), he 
should explain that his reason for enforcing the note is to advance his own class interest. Clear communication is essential to good decisionmaking.

As a substantive matter, I would not enforce the note. The entire community has an interest in the criminal appeal process. The mere property interest of a middle-class professional should not thwart communal goals. The real issues here are the social forces that led the thief to steal and the reasons for privileging the "owner's" claim to the property over the "thief's". It is mere pretense that apolitical "law" can save us from confronting these political issues.

\section{ALLEN: Very well. Perhaps we should get the view of a sitting judge?}

POSNER: Considering the books you have on your desk, I would hope you would now be able to predict my decision. ${ }^{14}$ I have, at least, been honest enough to try to explain how I think most cases should be decided. Quite frankly, my honesty in my writings has probably cost me a chance to sit on the Supreme Court, and I would hope Mr. Kelman and his compatriots might spare me at least the charge that I have engaged in "mystifying" decisionmaking-I have not hidden my values.

KELMAN: I will have to admit you have made my job easier. POSNER: Anyway, I have written:

Duress in its original sense implies a threat of violence. If $B$ gives a promissory note to A because A is holding a knife to B's throat, the courts [should] not compel B to make good on his note to A ... A's behavior retards rather than advances the movement of resources to their most valuable uses and creates deadweight losses . . ${ }^{15}$

Because Mr. Allen provides us with no precedent, I think the case is rightly resolved in reference to the above delineated efficiency concerns.

I do not think that duress can properly include uneven bargaining power in the open market. We should allow parties to contract freely, and we would create obstructions which harm everybody if we penalized the strong for contracting with the weak-

KELMAN: [interrupting] I don't think anyone is surprised by your position. You've sickened us before with your "freedom of contract"/"market efficiency" excuses for coercion. The essence of con-

14. See Posner, Economic Analysis of Law, 101-05 (3d ed. 1986).

15. Id. at 101 . 
tract is coercion. All contracts are signed under "duress". Your ridiculous defense of capital is nothing more than reactionary pandering.

POSNER: [unruffled] If you'd let me finish, I might make a further point about our fact situation. Unlike many so-called "unconscionable" contracts which deserve enforcement, the promissory note in question was executed as a direct result of a bilateral monopoly. No true bargaining could occur because the attorney completely controlled the market for his client's legal files and papers. In the case of salvors who come upon a sinking vessel, maritime courts award the salvor a "reasonable fee" for his rescue. Any outrageous promise to pay made by the captain of the sinking ship will not be enforceable. Monopolies are inefficient, and in the case of the salvor, the rule against the enforcement of hard bargains avoids high transaction costs.

If the conditions of the note were unreasonable, I, like Mr. Kelman, would void the note.

HOLMES: With all due respect, I would have no problem enforcing the note. I really am not interested in Professor Kelman's views about property rights or my brother Posner's views on economic efficiency. Either, or neither, of them may be right. What is "right" is irrelevant. My function as a judge is not to rewrite society's laws-at most I exercise a merely interstitial legislative function.

The legislature in our example has spoken. An attorney, by statute, may keep his client's files and papers until the bill is paid. Surely the legislature had in mind precisely the fact situation we have before us: an attorney using his superior leverage to obtain his fee (but only his fee-not some larger windfall amount). I smell the stench of interest group legislation here as much as the next fellow, but I refuse to invalidate a law just because it's stupid.

ALLEN: M. Pascal, I am sure, should be able to add a word. I hate to put you on the spot, especially since I am sure you personally would never have desired to sit as a judge on the daily affairs of men.

PASCAL: You are right, of course. But I take some interest in the little book you have given me. I think perhaps that I might posit a way to make a judicial decision in spite of my belief that in the long run no particular judicial method is going to yield a just society.

A judge's despair at the inability to change human nature should not diminish his obligation to act in good faith. My conception of man-its religious element aside-is somewhat similar to that posited 
by the Existentialists. Paradox and despair, the inability to transcend reality, plague mankind. The response, however, cannot be inaction. Even though trapped in a plague-infested city and doomed to die, Camus' doctor continued to practice his healing art. Hopelessness did not prevent his struggle, and to struggle is perhaps man's most essential attribute. Although my faith in God prevents me from extending existential despair into eternity, I borrow Camus and Sartre's concept of "good faith" as the only proper rationale for acting in the world.

ALLEN: Perhaps that explains your hopeless struggle against the Jesuits.

PASCAL: Perhaps.

A judge must decide a case in good faith. By this I mean several things. First, a judge must respond to the governmental and social powers which legitimate his function. As Mr. Holmes says, deference to the lawmaking authority is important. Also, I think good faith necessitates deference to past decisions-satisfaction of expectation interests of the parties and the need to forewarn Justice Holmes' bad man or Judge Posner's market actor would seem proper instrumental roles for a judge to play. I might note that these principles need not leave the law static. I realize the law develops, and I think Mr. Levi's description of how the law should change is laudable. ${ }^{16}$

KELMAN: That is very interesting to hear from the man who once wrote:

Veri Juris [true law]: we no longer have it: for if we did, we should not base our justice on following the customs of the country. ${ }^{17}$

PASCAL: Yes, but without the true law, what more do we have than custom or consensus-inefficient or irrational though they may be? I cannot purport to know the true law which would govern God's Utopia. And, because I believe that Professor Kelman's obsession with the redistribution of power and Judge Posner's reliance on efficiency either presuppose a Utopia of human construct or deny human nature, I must reject them as bases for good faith lawmaking.

I'm afraid I might seem like a fairly conventional judge-interpreting legislative intent, analyzing conflicting policies, searching for relevant precedent. But maybe, if I am acting in good faith, the critiques of my fellow panelists are valuable. Any increase in my awareness of self-interest (class bias for example) or inefficiency (when

16. E. Levi, An Introduction to Legal Reasoning (1949).

17. Fragment 297, supra note 5. 
efficiency is the goal) or other de-legitimating tendencies in my decisionmaking would certainly be positive.

KELMAN: I appreciate the bone you have just thrown Judge Posner and me, but I'm not sure I understand why you threw it. If you claim not to be sure of what true law is, how can you say that something acts to de-legitimate it? What if slavery is the custom or norm? Is it then legitimate or just?

HOLMES: I'm confused also. The "conventional judge" whom you describe sounds a lot like me. And yet you have made it clear that you fundamentally disagree with me.

PASCAL: I think I can address both of your questions. Professor Kelman, although I could never as a judge or a legislator or a king establish justice, that does not mean that I cannot be sure of some just principals. Sometimes, like Plato's characters watching the shadows play on the wall of their cave, we may perceive a reflection of God's truth despite his hidden nature. Life would be meaningless if we had absolutely no insight into the divine. Forces which contravene the principles derived from such glimpses are "illegitmate." Your example of slavery is a good one-regardless of custom or convention slavery is unjust.

KELMAN: [sarcastically] Well, slavery cases don't pop up too much in federal court anymore.

PASCAL: However, a wide range of cases involving unequal treatment still do flood the courts.

HOLMES: So, God has told you that Title VII plaintiffs should be given preferential treatment!

PASCAL: God has "told" me nothing. But I refuse to close my mind to him nonetheless, and I think that explains the basis of my differences with you.

I'm not saying that God has told me that a just court should always find in favor of the downtrodden. I am saying that when they lose, it should be because a consistent and neutral decision has been made on the merits, and not because of a particular judge's unconscious class bias. Any such bias is illegitimate. Equal treatment is a principal worth attempting to implement, and I reaffirm my previous statement that your various critiques might help a judge reduce his bias and more closely realize that unrealizeable principle.

POSNER: You seem to have taken my caveat about economics to heart:

[T] here is more to notions of justice than a concern for eff- 
ciency ... There may well be definite although wide boundaries on both the explanative and reformative power of economic analysis of law. Always, however, economics can provide value clarification by showing the society what it must give up to achieve a noneconomic ideal of justice. The demand for justice is not independent of its price. ${ }^{18}$

PASCAL: Sometimes it is necessary to pay the "price" you so sardonically speak of. Sometimes justice demands that a judge respond beyond the parameters of custom or convention or economics. The potential need for that response is what makes crucial the discussion by us cave-dwellers of what bits of "truth" and "justice" may have been revealed to us. Sometimes, good faith demands that a judge act on the basis of justice alone.

HOLMES: But how do we tell, for example, whether the right to a minimum wage is "just"?

PASCAL: I don't know. Listen, I have not given you an infallible method for truthseeking! There is none. I told you how a judge should decide a case-I did not say he would decide it correctly. I told you we should talk about justice; I did not tell you how to establish it.

POSNER: Even so, I am curious as to what you would decide in the test case given to us by Mr. Allen.

PASCAL: What's important is how I would decide it, and I've already tried to explain that. As to what I would decide, without a knowledge of the society in which the case arose or of its laws and history, I cannot say.

(As Kelman begins to speak, the sound fades and the camera pulls back slowly. The Announcer begins his promotion of the upcoming episode of "The Newhart Show" and cuts to a commercial.)

18. Posner, Economic Analysis of Law, 25-26, (3d ed. 1986). 
Heinonline -- 6 J. L. \& Religion 2961988 